\title{
Social and ecological outcomes of conservation interventions in tropical coastal marine ecosystems: a systematic map protocol
}

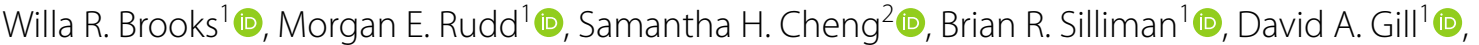 \\ Gabby N. Ahmadia ${ }^{3}$, Dominic A. Andradi-Brown ${ }^{3}$, Louise Glew ${ }^{4}\left(\mathbb{C}\right.$ and Lisa M. Campbell ${ }^{1 *}(\mathbb{C}$
}

\begin{abstract}
Background: Tropical coastal marine ecosystems (TCMEs) are rich in biodiversity and provide many ecosystem services, including carbon storage, shoreline protection, and food. Coastal areas are home to increasing numbers of people and population growth is expected to continue, putting TCMEs under pressure from development as well as broader environmental changes associated with climate change, e.g. sea level rise and ocean acidification. Attention to TCMEs by conservation organizations has increased and although a variety of interventions to promote conservation and sustainable development of TCMEs have been implemented, evidence regarding the outcomes of thesefor people or ecosystems - is scattered and unclear. This study takes a systematic mapping approach to identify articles that examine the ecological and social outcomes associated with conservation interventions in TCMEs; specifically in coral reef, mangrove, and seagrass habitats.
\end{abstract}

Methods: We developed a comprehensive framework of conservation interventions and outcomes, drawing on existing frameworks and related evidence synthesis projects, as well as interviews with marine conservation practitioners. We modified existing frameworks to: (i) include features of TCME that are not fully captured in existing frameworks; and (ii) further specify and/or regroup existing interventions or outcomes. We developed a search string informed by habitat, geography, interventions, and outcomes of interest, to search the peer-reviewed primary literature in four bibliographic databases and the grey literature on relevant institutional websites. All searches will be conducted in English. We will screen returned articles at the title and abstract level. Included articles will be screened at full text level and data coding will follow. Number of articles and reasons for excluding at full text level screening will be recorded. At each phase (title and abstract screening, full text screening, data coding), articles will be assessed independently by two members of the review team. Coded data will be reported in a narrative review and a database accessible through an open access, searchable data portal. We will summarize trends in the evidence base, identify interventions and outcomes where evidence can be further assessed in subsequent systematic reviews and where gaps in the literature exist, and discuss the implications of research gaps and gluts for TCME conservation policy, practice, and future research.

Keywords: Ecosystem functions, Ecosystem services, Human well-being, Governance, Coral, Mangrove, Seagrass

*Correspondence: lisa.m.campbell@duke.edu

1 Duke University Marine Lab, Nicholas School of Environment, Duke

University, 135 Duke Marine Lab Road, Beaufort, NC 28516, USA

Full list of author information is available at the end of the article

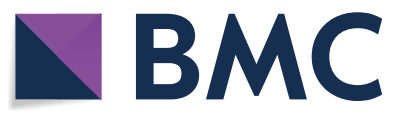

(c) The Author(s) 2020. This article is licensed under a Creative Commons Attribution 4.0 International License, which permits use, sharing, adaptation, distribution and reproduction in any medium or format, as long as you give appropriate credit to the original author(s) and the source, provide a link to the Creative Commons licence, and indicate if changes were made. The images or other third party material in this article are included in the article's Creative Commons licence, unless indicated otherwise in a credit line to the material. If material is not included in the article's Creative Commons licence and your intended use is not permitted by statutory regulation or exceeds the permitted use, you will need to obtain permission directly from the copyright holder. To view a copy of this licence, visit http://creativeco mmons.org/licenses/by/4.0/. The Creative Commons Public Domain Dedication waiver (http://creativecommons.org/publicdomain/ zero/1.0/) applies to the data made available in this article, unless otherwise stated in a credit line to the data. 


\section{Background}

Coastal areas are home to much of the world's human population, with roughly half living within $100 \mathrm{~km}$ of the coast [1] and coastal population growth expected to continue [2]. Coastal marine ecosystems support a significant portion of the global economy, estimated at US $\$ 24$ trillion [1], and provide critical ecosystem services including carbon storage, shoreline protection, and food [3, 4]. Globally, more than 775 million people are highly dependent on coastal marine ecosystems [5]. On food provision alone, the FAO estimates that fish provide 3.2 billion people with $20 \%$ of their protein, and a higher percentage in developing countries. Fish also provide critical micronutrients and are especially important in the diets of residents of small island developing states [6]. Additionally, fisheries and aquaculture provide employment, livelihoods, and cultural identity for 56.9 million people [6].

Coastal marine ecosystems are vulnerable to both increased and intensified development activity and related environmental change, and the impacts of human activities on coastal marine ecosystems are of increasing concern [7]. Habitat coverage and quality have declined across habitat types (e.g. oyster reefs, salt marshes, coral reefs, seagrasses, and mangroves) and climate change and associated sea level rise are predicted to exacerbate already increasing rates of degradation $[2,8,9]$. In tropical regions, coastal marine ecosystems support diverse, productive ecosystems; coral reefs, mangroves, and seagrasses are of particular interest to conservation organizations because of their biodiversity value and the other ecosystem services they provide. All three habitats have experienced declines in habitat quality and spatial extent. For example, $35 \%$ of mangroves have been lost [10] and the global rate of mangrove forest loss is estimated as 5 times the average rate of global forest loss [11]. Seagrasses have declined globally by $29 \%$ [9]. Although $27 \%$ of coral reefs are protected, $75 \%$ are considered threatened [12] and over $50 \%$ have been lost [1].

Coral reef ecosystems have received considerable attention by scientists, conservationists, and governments. There are numerous organizations and initiatives dedicated to coral reef conservation (e.g. Coral Reef Alliance, International Coral Reef Initiative) and long standing coral reef conservation programs in larger conservation organizations. The Convention on Biological Diversity has among its 20 Aichi Biodiversity Targets for 2020 one specific to coral reefs (Target 10), the only marine habitat singled out for protection. Mangroves and seagrasses have received less and little coordinated attention by conservation organizations, although this is changing for mangroves. In 2014, the UNEP published a Call to Action for mangroves [11] and the Global Mangrove Alliance was launched in June 2017. Seagrasses continue to receive less attention, but efforts to organize are apparent (e.g. the World Seagrass Association campaign for a World Seagrass Day).

Increased recognition of the value of mangroves and seagrasses reflects a general increase in interest in and support for ocean conservation over the past several decades [13] as well as calls for a more holistic ecosystem based approaches to ocean conservation [14]. Philanthropic support has also grown and in 2015 philanthropies provided about half of a (conservative) estimate of $\$ 800$ M USD grant funding for ocean conservation [15]. To date, ocean conservation interventions have been dominated by the establishment of marine protected areas (MPAs) by national governments [16]. Although protected areas generally have long been mired in a 'parks versus people' debate [17], and their impacts on people are debated $[18,19]$, most contemporary conservation efforts recognize the need to deliver benefits to human communities. This need arises from practical (communities have high stakes in conservation outcomes; community support can be critical to success), philosophical (humans are part of ecosystems), and ethical (local people bear disproportionate costs of conservation) concerns [20], and these concerns are reflected in a number of contemporary conservation approaches, including, 'ecosystem services' [10], 'nature's contributions to people' [21], 'rights based conservation' [22], or 'new conservation' [23]. Interest in delivering benefits to people via conservation means that the social outcomes of MPAs have received increased attention (e.g. [24-26]), and that conservation organizations have diversified both the tools they use to promote conservation (e.g. rights based fisheries, certification schemes, payments for ecosystem services, community-based conservation, etc.) and approaches to implementation (e.g. through bottom up, participatory processes, social media campaigns, education and capacity building, etc.). Achieving positive social outcomes, or at least minimizing negative ones, is now considered critical to ethical conservation [24]. As need, interest, and funding for tropical coastal marine ecosytem (TCME) conservation grows, it is timely to consider the extent of current evidence regarding the outcomes of conservation interventions to date.

Like other fields of conservation, there is a growing but scattered body of literature on the social or ecological outcomes of conservation interventions in TCMEs, which limits clear understanding of the extent and strength of evidence available to inform decisions in marine conservation [27]. While a handful of reviews and 
syntheses have investigated specific marine conservation interventions and their subsequent outcomes, they have been limited in scope, typically focusing on one type of marine intervention (e.g. MPAs [28]) and either ecological or social outcomes (e.g. [26]). For example, recent and ongoing evidence syntheses efforts have focused on the efficacy of partially and fully protected MPAs [29], socioeconomic factors that influence how MPAs impact on ecosystems and livelihoods [30], impacts of energy systems on marine ecosystem services [31], knowledge gaps related to cultural ecosystem services provided by coastal marine ecosystems [32], seafood certification [33], and future prospects of coastal marine ecosystem services [34]. Our review aims to scope and identify existing articles that document evidence of social or ecological impacts from a broad suite of conservation interventions within TCMEs.

\section{Stakeholder engagement}

Staff on the Ocean Conservation and Science teams at World Wildlife Fund-US (WWF) (Ahmadia, AndradiBrown, Glew), researchers at Duke University's Nicholas School of Environment (Campbell, Brooks, Gill, Rudd, Silliman), and Dr. Samantha Cheng (American Museum of Natural History) collaborated to formulate the review question and scope of this systematic map. WWF is an international conservation non-profit organization that supports ongoing tropical marine conservation efforts. Although WWF initiated the collaboration, the goal is to produce a map that can inform the work of conservation organizations and other stakeholders supporting conservation in TCMEs.

Our multi-organizational team of practitioners, researchers, and evidence synthesis specialists held several planning meetings to agree on the scope of the map and to develop a conceptual framework for this study, and these were further refined based on insights from informational interviews with marine conservation practitioners who also had experience with systematic mapping. Overall, our interests are in a broadly scoped review of TCMEs, and we worked to balance this interest with project feasibility. Conceptually, we are interested in direct impacts of conservation interventions on people and/or TCMEs, as well as indirect impacts (Fig. 1). In order to include a broad suite of interventions as well as multiple social and ecological outcomes, we narrowed our focus on TCMEs to coral reefs, mangroves, and seagrasses. Even with this narrowing, the scope is broad in comparison with many other reviews. This broad scoping is possible through Duke University's Bass Connections program, which facilitates student participation in research projects as part of the educational experience. We planned our review project knowing a large team of undergraduate and graduate students $(\mathrm{n}=10-20)$ will be available to assist with screening each semester, and that we will be able to run the project in multiple years. The project is funded through Bass Connections core funding as well as funding made available to both Duke and WWF to support collaboration.

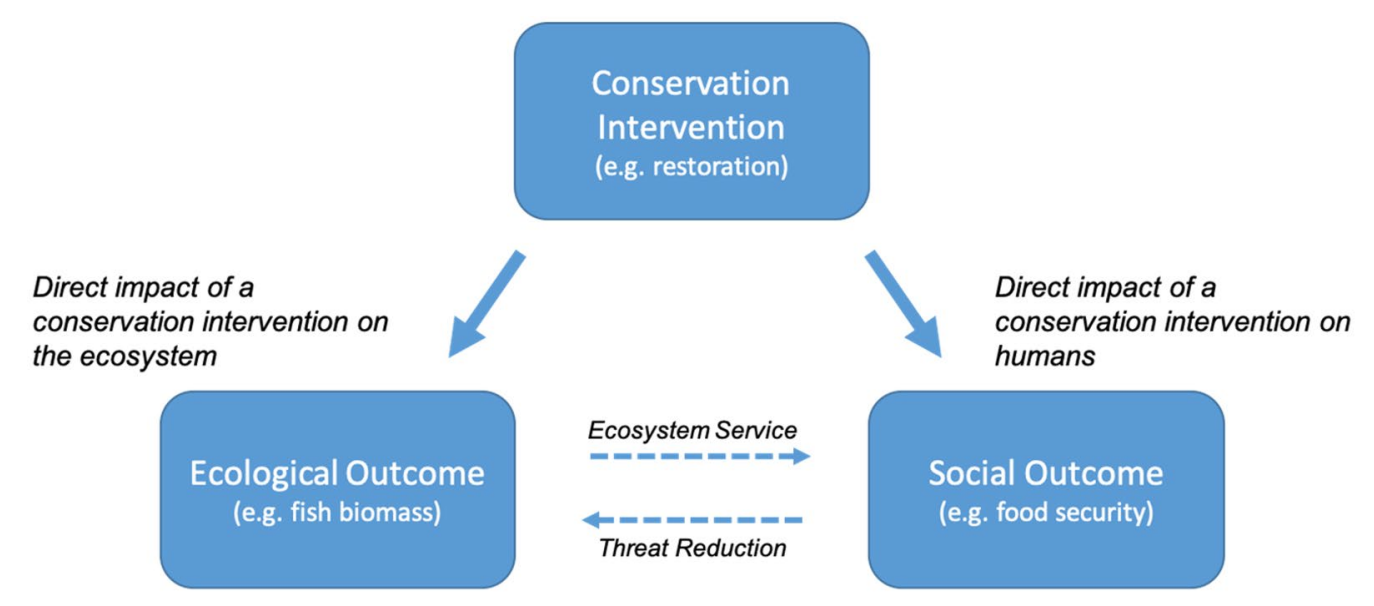

Indirect impact of conservation intervention

Fig. 1 Conceptual framework depicting direct and indirect impacts from conservation interventions on ecological and social outcomes. Bold arrows indicate direct impacts of the intervention. Dashed arrows indicate indirect impacts of the intervention (e.g. the restoration of a habitat directly results in an increase in fish biomass, which then enhances food security in a local community) 


\section{Framework development}

The IUCN-Conservation Measures Partnership's (IUCN-CMP) Conservation Actions v2.0 was developed to provide a uniform framework for conservation interventions [35]. This framework identifies three distinct conservation interventions or action types: (i) target restoration/stress reduction actions, (ii) behavioral change/threat reduction actions, and (iii) enabling condition actions. Within these three action types are 10 conservation action categories: (1) land/water management, (2) species management, (3) awareness raising, (4) law enforcement and prosecution, (5) livelihood, economic, and moral incentives, (6) conservation designation and planning, (7) legal and policy frameworks, (8) research and monitoring, 9) education and training, and 10) institutional development. Building on this pre-existing framework ensures uniformity in our designation of conservation actions, and allows for reproducible and/or comparable results in future studies. Although some marine issues and examples are included in the framework, most are terrestrial, so we adapted the IUCN-CMP framework (with input and feedback from interviews with marine conservation practitioners) to better represent TCMEs. For example, we added the subcategories of habitat management and fisheries management to the species management category, as both are relevant to managing marine species at different life stages (e.g. habitat management might be relevant at the larval stage). Further, in contrast to many wild terrestrial species targeted for conservation, fish are frequently harvested making fisheries management relevant for conservation. The adaptation of the IUCN-CMP typology itself is a valuable contribution, providing a framework to better understanding the evidence base for marine conservation interventions.

We compiled our conservation outcomes framework from existing systematic reviews and syntheses on conservation topics [36-38], a pre-existing theory-based framework for analyzing conservation impacts [39], and the Millennium Ecosystem Assessment [10]. We identified and synthesized seven outcome categories of interest: (1) animal population/species, (2) ecological community, (3) ecosystem function, (4) ecosystem services, (5) human knowledge and behavior, (6) human well-being, and (7) governance. We modified existing human wellbeing outcome frameworks (e.g., [36], to recognize governance as a separate outcome category, distinct from human well-being. We define governance as "the formal and informal institutions through which authority and power are conceived and exercised" [40], and recognize that conservation interventions can reshape governance systems, in ways that may be positive, negative or neutral for both social and ecological outcomes. In this way, we classify governance as a potential mediator of social or ecological outcomes, as well as an outcome in its own right. We also further expand on the types of relations and processes that constitute governance in our framework, in order to provide additional clarity.

Our intervention and outcome framework (Additional file 1: Intervention framework \& Additional file 2: Outcome framework) were finalized after a workshop in September 2018 during which the majority of the collaborators and review team members were able to meet in person, discuss the frameworks, agree on definitions, and test their application to sample articles.

\section{Objective of the review}

The primary objective of this systematic map is to identify and describe the evidence base surrounding the social or ecological outcomes of a broad range of conservation interventions undertaken in TCMEs, and specifically in tropical coral reef, mangrove, and seagrass ecosystems (Table 1). The map can direct further research into evaluating the evidence base, through systematic reviews and meta-analyses of results.

We limited the geographic scope of the study to tropical coastal marine ecosystems. In doing so, we distinguished among ecological (e.g. species present, ecosystem characteristics), social-economic (e.g. GDP, direct reliance of communities on coastal marine resources), and governance (e.g. role of state and non-state actors in governance, poverty alleviation mandates) characteristics in tropical, primarily low-income and lower-middle-income countries of the Global South. Although the distinction is imperfect and

\section{Table 1 Key elements of review question}

\begin{tabular}{|c|c|c|c|}
\hline Population & Intervention & Comparator & Outcome \\
\hline $\begin{array}{l}\text { Individuals animals, popula- } \\
\text { tions, species, ecological } \\
\text { communities, and/or human } \\
\text { communities that live within } \\
\text { and/or rely on tropical coral } \\
\text { reef, mangrove, or tropical } \\
\text { seagrass habitats }\end{array}$ & $\begin{array}{l}\text { Adoption or implementation of } \\
\text { coastal marine conservation } \\
\text { intervention (see Table } 3 \text { ) }\end{array}$ & $\begin{array}{l}\text { Comparison of intervention } \\
\text { types, impacts over time, over } \\
\text { space, against a control, or } \\
\text { among groups }\end{array}$ & $\begin{array}{l}\text { Impacts on human well-being, attitudes, behav- } \\
\text { ior, or knowledge OR on individual animals, } \\
\text { populations, species, ecological communities, } \\
\text { or habitats (see Table 4) }\end{array}$ \\
\hline
\end{tabular}


coarse, narrowing in on the tropics allowed us to capture a broader suite of outcomes in our map (e.g. both ecological and social outcomes) than would be possible otherwise. Further, as noted above, the vulnerability and resource dependency of people using TCMEs suggest that they should be a high priority for both science and conservation practice.

Our goal is to provide a map that details the extent of the literature directed at assessing evidence of the social or ecological outcomes of a broad range of conservation interventions in TCMEs, and specifically coral reefs, mangroves, and seagrasses. The map will highlight promising areas for further detailed investigation to assess the nature of the relationships (e.g. strength of evidence, directionality, durability, etc.) between interventions and outcomes. It will also highlight interventions for which there is little existing research. Ultimately, we hope to provide direction for scientific, philanthropic, government, and non-government organizations as they decide how to invest limited resources in programs, policies, research and interventions in these critical tropical coastal marine ecosystems.

This systematic map seeks to answer the following review question:

1. What is the extent and occurrence of articles that examine the effects of conservation interventions on ecological or social outcomes within tropical coral reefs, mangroves, and seagrass ecosystems?

We will also address the following secondary review questions:

a. What are the characteristics of the evidence base in terms of habitats, geography, study design, geographic scale, and outcomes studied?

b. What linkages between interventions and outcomes are most represented in the evidence base, and thus promising areas for further evaluation, analysis and synthesis?

c. What interventions and outcomes are less represented in the evidence base, thus requiring additional investigation?

\section{Methods}

ROSES forms and reporting standards [41] were followed to ensure compliance with CEE systematic synthesis guidelines (Additional file 3: ROSES form for systematic map protocols).

\section{Search for articles}

\section{Search terms}

We developed a search string comprising five distinct sub-strings. The five sub-strings represent: coastal qualifiers, population, intervention, outcome, and change strings. We developed individual search terms based on our population and conservation interventions and outcomes of interest. We tested each search term for sensitivity, wildcards (e.g. conserv*), and alternate wording (Additional file 4: Evolution of search string).

\section{Marine-coastal qualifying terms}

$\mathrm{TS}=($ "marine" OR "coastal" OR "fisheries" OR "fishery")

AND

\section{Population terms}

$\mathrm{TS}=($ coral OR mangrove OR seagrass OR SAV OR "submerged aquatic vegetation" OR communit" OR stakeholder OR habitat OR people OR resource OR ecosystem)

\section{AND}

\section{Intervention terms}

$\mathrm{TS}=($ conserve OR conserving OR conserved OR conservation OR restoration OR restore OR reintroduction OR gear OR quota OR "catch limit" OR "size limit" OR moratorium OR "fishing ban" OR "endangered species" OR "threatened species" OR advocacy OR awareness OR communication OR patrol" OR compliance OR enforcement OR ecotourism OR "alternative livelihoods" OR stewardship OR "payments for ecosystem services" OR PES OR subsidies OR LMMA OR "marine park" OR "marine reserve" OR MPA OR "marine protected area" OR "biosphere reserve" OR "restricted area" OR "marine sanctuary" OR "no take" OR "area closure" OR "buffer zone" OR "access rights" OR "marine spatial plan"” OR "marine plan" OR "action plan" OR "pollution mitigation" OR "wastewater treatment" OR "runoff treatment" OR law OR policy OR govern* OR CITES OR ESA OR "endangered species act" OR train* OR education OR capacity-build" OR partnership OR "blue carbon" OR CBNRM OR co-management OR media OR certification OR (invasive NEAR/3 (removal OR manag*)) OR (management NEAR/3 (fisher* OR "locally managed" OR "watershed" OR community-based OR "natural resource" OR "natural resources" OR "ecosystem-based" OR "ecosystem based" OR "harvest" OR "area")))

\section{AND}

\section{Outcome terms}

$\mathrm{TS}=($ awareness OR adoption OR "willingness to" OR ((population OR species) NEAR/3 (abundance OR biomass OR density OR diversity OR "genetic diversity" OR productivity OR fecundity OR reproducti* OR 
distribution OR range OR dispersal OR migration)) OR "genetic diversity" OR "ecosystem service" OR "ecosystem services" OR "coral cover" OR "habitat cover" OR degradation OR recovery OR "functional diversity" OR "community composition" OR well-being OR "well being" OR well-being OR welfare OR security OR livelihood OR job OR employment OR asset OR income OR decisionmaking OR govern* OR empowerment OR participat* OR equity OR "human health" OR nutrition OR mortality OR disease OR consumption OR skill OR degree OR training OR literacy OR access OR "water clarity" OR "water quality" OR sanitation OR "building materials" OR housing OR fuel OR expenditure OR safety OR adapt* OR resilienc* OR engagement OR "carbon sequestration" OR "carbon sink" OR "carbon storage" OR "coastal protection" OR "shoreline protection" OR erosion OR "air quality" OR "air pollutants" OR biodiversity OR richness)

AND

Change terms

$\mathrm{TS}=($ change $\mathrm{OR}$ effect* $\mathrm{OR}$ impact OR recover* OR contribute)

\section{Searching the literature}

We will conduct searches using this string across a range of resources including: publication databases, organizational websites, key informants, relevant bibliographies, and grey literature. Search results will be limited to the English language, the language of our review team.

\section{Publication database searches}

Four publication databases will be searched:

Web of Science

1. An Advanced Search of All Databases will be conducted within Web of Science.

a. Databases include: Web of Science Core Collection, BIOSIS Citation Index, Current Contents Connect, Data Citation Index, Derwent Innovations Index, KCI-Korean Journal Database, Medline ${ }^{\circledR}$, Russian Science Citation Index, SciELO Citation Index, and Zoological Record.

2. All Years (beginning 1864) will be searched.

3. The language selected will be English.

4. The field tag TS will be used. This tag searches document title, abstract, and keywords for the selected search terms.

\section{Scopus}

1. Advanced Search
2. The field code TITLE-ABS-KEY will be used. This code searches for terms in the document title, abstract, and keywords.

\section{CAB Abstracts}

1. An Advanced Search of Cab Abstracts* and Cab Abstracts Archive* will be conducted within $\mathrm{CAB}$ Abstracts.

2. Search Modes and Expanders

a. Search modes: Boolean/Phase

3. Limit your results

a. Publication Type: $A l l^{*}$

4. Special limiters for $C A B$ Abstracts

a. Broad Category: All*

5. Special limiters for $C A B$ Abstracts Archive

a. Subject Subset: $A l l^{*}$

6. Select a Field

a. TI Title

b. AB Abstract

c. SU Subject Terms

Aquatic Sciences and Fisheries Abstracts (ASFA)

1. Advanced Search

a. All databases, publication dates (1940-2018), sources, subjects, and document types will be searched, including peer reviewed and nonpeer reviewed literature.

2. The field tags, TI, AB, and IF will be used to limit searches to document title, abstract, and keywords/ identifiers for search terms.

\section{Targeted searches and grey literature}

We will search organizational websites (identified by key informants and through a review of other systematic reviews) for relevant additional literature (both peerreviewed and grey unpublished literature) (Table 2). We will also check web-based bibliographies identified during the web searching phase for additional references.

\section{Comprehensiveness of the search}

Initial scoping exercises performed in Web of Science, Scopus, CAB abstracts, and ASFA yielded approximately 104,987 potentially relevant articles. A reference library 
Table 2 Organizational websites

\begin{tabular}{|c|c|}
\hline Organization & Website \\
\hline A Rocha International & http://www.arocha.org/en/ \\
\hline Biodiversity Support Program & $\begin{array}{l}\text { https://rmportal.net/library/conte } \\
\text { nt/tools/biodiversity-suppo } \\
\text { rt-program }\end{array}$ \\
\hline $\begin{array}{l}\text { California Cooperative Oceanic } \\
\text { Fisheries Investigations }\end{array}$ & http://www.calcofi.org/ \\
\hline $\begin{array}{l}\text { Caribbean Natural Resources } \\
\text { Institute }\end{array}$ & https://www.canari.org/ \\
\hline $\begin{array}{l}\text { Centre for Environment, Fisheries \& } \\
\text { Aquaculture Science }\end{array}$ & http://www.cefas.defra.gov.uk/ \\
\hline Conservation International & https://www.conservation.org/ \\
\hline $\begin{array}{l}\text { Collaboration for Environmental } \\
\text { Evidence library }\end{array}$ & $\begin{array}{l}\text { http://www.environmentalevidenc } \\
\text { e.org/ }\end{array}$ \\
\hline Conservation Evidence & $\begin{array}{l}\text { https://www.conservationevidence } \\
\text {.com/ }\end{array}$ \\
\hline Coral Reef Alliance & https://coral.org/ \\
\hline $\begin{array}{l}\text { Coral Reef MPAs of East Asia and } \\
\text { Micronesia }\end{array}$ & http://mpa.reefbase.org/ \\
\hline $\begin{array}{l}\text { Department of Conservation, New } \\
\text { Zealand }\end{array}$ & http://www.doc.govt.nz/ \\
\hline $\begin{array}{l}\text { Department for Environment, Food } \\
\text { and Rural Affairs }\end{array}$ & http://www.defra.gov.uk \\
\hline $\begin{array}{l}\text { Department of Sustainability, Envi- } \\
\text { ronment, Water Australia }\end{array}$ & http://www.environment.gov.au/ \\
\hline Food and Agriculture Organization & http://www.fao.org/ \\
\hline Global Mangrove Alliance & http://www.mangrovealliance.org/ \\
\hline $\begin{array}{l}\text { International Institute for Environ- } \\
\text { ment and Development }\end{array}$ & https://www.iied.org/ \\
\hline The Nature Conservancy & https://www.nature.org/ \\
\hline $\begin{array}{l}\text { International Union for the Conser- } \\
\text { vation of Nature }\end{array}$ & https://www.iucn.org/ \\
\hline $\begin{array}{l}\text { Joint Nature Conservation Com- } \\
\text { mittee }\end{array}$ & http://jncc.defra.gov.uk/ \\
\hline $\begin{array}{l}\text { Locally-Managed Marine Area } \\
\text { Network }\end{array}$ & http://Immanetwork.org/ \\
\hline NatureServe & http://www.natureserve.org/ \\
\hline $\begin{array}{l}\text { NCCOS Center for Coastal Monitor- } \\
\text { ing and Assessment }\end{array}$ & https://coastalscience.noaa.gov/ \\
\hline $\begin{array}{l}\text { NOAA National Marine Protected } \\
\text { Areas Center }\end{array}$ & http://mpa.gov/ \\
\hline Rare & https://www.rare.org/ \\
\hline $\begin{array}{l}\text { United Nations Environment Pro- } \\
\text { gramme (UNEP) }\end{array}$ & https://www.unenvironment.org/ \\
\hline $\begin{array}{l}\text { UNEP World Conservation Monitor- } \\
\text { ing Center }\end{array}$ & https://www.unep-wcmc.org/ \\
\hline $\begin{array}{l}\text { United Nations Development } \\
\text { Programme }\end{array}$ & $\begin{array}{l}\text { http://www.undp.org/content/ } \\
\text { undp/en/ }\end{array}$ \\
\hline $\begin{array}{l}\text { United States Agency for Interna- } \\
\text { tional Development }\end{array}$ & https://www.usaid.gov/ \\
\hline $\begin{array}{l}\text { USAID Development Experience } \\
\text { Clearinghouse }\end{array}$ & https://dec.usaid.gov/dec/home/ \\
\hline Wildlife Conservation Society & https://www.wcs.org/ \\
\hline World Bank & http://www.worldbank.org/ \\
\hline World Wide Fund For Nature & https://www.worldwildlife.org/ \\
\hline
\end{tabular}

of 20 articles was developed to check to the comprehensiveness of the search strategy (Additional file 5: Article test library). Reference articles were compiled from previous systematic maps and reviews, key informants, and general searches on the internet. Searches were refined until at least $75 \%$ of the of the reference articles were retrieved.

\section{Review phases}

To accommodate the large number of articles returned by our search strategy, we plan to work in phases, for example, by limiting our initial screening and data coding to a $10 \%$ random sample of the returned articles. The subset will be identified using Excel's random number generator to select article Record IDs in EndNote. A 10\% sample provides a number of articles that exceeds the threshold required for a 95\% confidence level, with 1 margin of error, that the sample represents the total population of articles. Working in phases will help to ensure that student team members realize progress and participate in both article screening and data coding over the course of their participation in the project.

\section{Reference management}

The titles and abstracts of candidate articles identified through the search strategy will be downloaded from the four bibliographic databases and uploaded into Endnote X8. Duplicate articles will be identified and removed via Endnote's Find Duplicates tool. Once duplicates are removed, search hits will be imported and screened (title/ abstract, full text) in Colandr, an open-access, machinelearning assisted tool for conducting evidence syntheses [42]. A single member from the research team will manage the EndNote library and assign articles to the various Colandr accounts for members of the review team to screen.

\section{Article screening and study eligibility criteria Screening process}

All articles will be screened by members of the review team, which includes the Duke research team and students participating in the Bass Connections project. Each screener will be extensively trained during weekly project meetings and in smaller work groups. Articles will first be screened at the title/abstract level. Each article will be double-screened to ensure consistency between reviewers; each individual screener will screen with other members of their group, and we will avoid pairs of screeners always working together. Uncertainties and conflicts in screening decisions at both title/abstract and full text review stages will be discussed and resolved between reviewer pairs, with larger discussion by the review team 
if necessary. Weekly discussion meetings will ensure that screeners share an understanding of screening and data coding protocols, and will help avoid 'drift' (i.e. where some screeners develop their own interpretation of protocols). All screening decisions at both stages will be recorded and made available. Review team members will not be permitted to screen articles they have co-authored.

\section{Eligibility criteria}

Articles meeting the following criteria will be included:

\section{Population}

In order to fully capture the extent of impacts on social or ecological components of tropical coastal marine systems, we include articles examining both species and human populations (e.g. individuals, households communities, and/or nation states) that directly rely on these habitats. Specifically, we include articles that examine species that rely on these habitats for survival (e.g. key life stages) and human populations that are directly reliant, adjacent, or inextricably connected to tropical coral reef, mangrove, or seagrass habitats. We will exclude articles that do not have a clearly defined affected population (e.g. global good, coastal ecosystems broadly, etc.) or focus on non-tropical or deep sea habitats/species (e.g. cold water corals, temperate seagrasses) or highly migratory species where these ecosystems do not represent a major part of their life history (e.g. tuna).

\section{Intervention}

We will focus on articles that evaluate the establishment, adoption, or implementation of conservation interventions that aim to manage, restore, improve, or increase the capacity of a site, area, natural process, or species within coral, mangrove, or seagrass ecosystems. Intervention types are: land/water management; species management; awareness raising; enforcement and prosecution; livelihood, economic, and other incentives; conservation designation and planning; legal and policy frameworks; research and monitoring; education and training; and institutional/organizational development (Table 3; Full table with examples in Additional file 1: Intervention framework).

\section{Outcome}

We will include articles that describe impacts on one or more domains of ecosystem health (population/species abundance/diversity, community structure, ecosystem condition/habitat cover, ecosystem services), knowledge and behavior change, human well-being, and governance.
Specifically, we will include articles that attempt to evaluate or document change in and across these elements for both observed and perceived outcomes (Table 4; Full table with examples in Additional file 2: Outcome framework).

Intervention framework adapted from IUCN CMP Actions Classification v2.0 framework

\section{Study design}

We will include articles that attempt to evaluate or document the impacts of a conservation intervention using a relevant comparator. This includes experimental, quasiexperimental, and non-experimental, narrative, and observational studies. We will exclude theoretical studies, theses and dissertations, opinion pieces, studies where outcomes are modeled or predicted, studies where the population is not defined, and non-systematic literature reviews.

\section{Comparator}

Studies with a comparator will be included. This includes temporal comparators (before/after, time series), spatial comparators (distance from site, between different sites), among groups (inside/outside intervention areas, demographic groups), between control and intervention (with/ without). Quantitative and qualitative studies of natural and social outcomes will be included, provided there is an attempt to evaluate or document change in relation to the interventions of interest. Studies may document actual change, or change as perceived by people. Recognizing that strict comparators are difficult to ensure with in situ conservation work involving ecosystems and people, screeners will err on the side of inclusion during both screening and data coding.

\section{Study validity assessment}

A critical appraisal of study quality and strength will not be formally undertaken at this stage of the study, although the internal validity of included articles can be heuristically evaluated using information from the data coding questionnaire. The primary objective of our map will be to characterize the extent and distribution of the evidence base through identifying all relevant literature using our comprehensive search, detailed above.

\section{Data coding strategy}

The initial data coding questionnaire was developed through an iterative process. We will code data in relation to five broad categories: (1) reviewer information, (2) bibliographic information, (3) basic information on study location, scope, design and habitat, (4) conservation interventions, and (5) ecological and social outcomes (Additional file 6: Data coding questionnaire). 
Table 3 Categories and subcategories of conservation interventions

\begin{tabular}{|c|c|c|}
\hline Intervention category & Intervention definition & Intervention subcategory \\
\hline 1. Land/Water Management & $\begin{array}{l}\text { Actions directly managing or restoring sites, eco- } \\
\text { systems and the wider environment }\end{array}$ & $\begin{array}{l}\text { 1a. Site/Area Stewardship } \\
\text { 1b. Restoration } \\
\text { 1c. Ecosystem \& Natural Process Management }\end{array}$ \\
\hline 2. Species Management & $\begin{array}{l}\text { Actions directly managing or restoring specific } \\
\text { species or taxonomic groups }\end{array}$ & $\begin{array}{l}\text { 2a. Habitat (seagrass, mangroves, coral reef) } \\
\text { management } \\
\text { 2b. Fisheries management } \\
\text { 2c. Species stewardship } \\
\text { 2d. Species Reintroduction and Translocation } \\
\text { 2e. Ex-Situ Conservation }\end{array}$ \\
\hline 3. Awareness Raising & $\begin{array}{l}\text { Actions making people aware of key issues and/ } \\
\text { or feeling desired emotions, attitudes, opinion } \\
\text { designed lead to behavior change }\end{array}$ & $\begin{array}{l}\text { 3a. Outreach \& Communications } \\
\text { 3b. Protests \& Civil Disobedience } \\
\text { 3c. Political Lobbying and Campaigning }\end{array}$ \\
\hline 4. Enforcement \& Prosecution & $\begin{array}{l}\text { Actions monitoring and enforcing compliance } \\
\text { with existing laws and policies (including cus- } \\
\text { tomary) at all levels to deter threats or compel } \\
\text { conservation action }\end{array}$ & $\begin{array}{l}\text { 4a. Monitoring/Detection } \\
\text { 4b. Criminal Prosecution \& Conviction } \\
\text { 4c. Non-Criminal Legal Action } \\
\text { 4d. Customary law/rule enforcement }\end{array}$ \\
\hline 5. Livelihood, Economic, and other Incentives & $\begin{array}{l}\text { Actions using livelihood, other economic and } \\
\text { moral incentives to directly influence attitudes } \\
\text { and behaviors }\end{array}$ & $\begin{array}{l}\text { 5a. Linked Enterprises \& Alternative Livelihoods } \\
\text { 5b. Consumer or producer substitution, through } \\
\text { technology or product innovation } \\
\text { 5c. Corporate practices and engagement } \\
\text { 5d. Market-Based Incentives } \\
\text { 5e. Direct Economic Incentives } \\
\text { 5f. Social and cultural values } \\
5 \mathrm{~g} \text {. Agency incentives } \\
5 \mathrm{~h} \text {. Resource use incentives }\end{array}$ \\
\hline 6. Conservation Designation \& Planning & Actions directly protecting sites and/or species & $\begin{array}{l}\text { 6a. Protected Area Designation \&/Or Acquisition } \\
\text { 6b. Easements \& Resource Rights } \\
\text { 6c. Land/Water Use Zoning \& Designation; marine } \\
\text { spatial planning } \\
\text { 6d. Conservation Planning } \\
\text { 6e. Community based planning for resource man- } \\
\text { agement and conservation } \\
\text { 6f. Site Infrastructure }\end{array}$ \\
\hline 7. Legal \& Policy Frameworks & $\begin{array}{l}\text { Actions developing and influencing legislation, } \\
\text { policies and voluntary standards affecting } \\
\text { conservation }\end{array}$ & $\begin{array}{l}\text { 7a. Laws, Regulations, \& Codes } \\
\text { 7b. Policies \& Guidelines } \\
\text { 7c. De jure property rights }\end{array}$ \\
\hline 8. Research \& Monitoring & $\begin{array}{l}\text { Actions collecting data and transforming it into } \\
\text { information to support conservation work }\end{array}$ & $\begin{array}{l}\text { 8a. Basic Research \& Status Monitoring } \\
\text { 8b. Evaluation, Effectiveness Measures, \& Learning }\end{array}$ \\
\hline 9. Education \& Training & $\begin{array}{l}\text { Actions enhancing the knowledge and skills of } \\
\text { specific individuals }\end{array}$ & $\begin{array}{l}\text { 9a. Formal education } \\
\text { 9b. Informal education } \\
\text { 9c. Training }\end{array}$ \\
\hline 10. Institutional/organizational development & $\begin{array}{l}\text { Actions creating the formal institutions and } \\
\text { organizations needed to support conservation } \\
\text { work }\end{array}$ & $\begin{array}{l}\text { 10a. Internal Organizational Management \& } \\
\text { Administration } \\
\text { 10b. External Organizational Development \& } \\
\text { Support } \\
\text { 10c. Alliance \& Partnership Development } \\
\text { 10d. Financing Conservation }\end{array}$ \\
\hline
\end{tabular}

Intervention framework adapted from IUCN CMP Actions Classification v2.0 framework

Data coding for each article will be completed by two reviewers and conflicts will be reconciled between them, consulting the larger review team if needed.

\section{Study mapping and presentation}

We will summarize the resulting dataset to compile descriptive statistics, such as article publication by year, frequency of comparator type, geographic distribution of study locations, frequency and distribution of study design for evaluating type of outcomes, or change in study interventions and outcomes over time, using the $\mathrm{R}$ statistical software (version 3.6). We will produce a series of intervention-outcome matrices populated with counts of studies within each intervention-outcome (and associated sub-group) pairs (e.g. heat maps). This will allow us to identify where evidence is lacking and potential areas for future research. We will also produce geographic maps showing the spatial distribution of 
Table 4 Categories and subcategories of environmental and social outcomes

\begin{tabular}{|c|c|c|}
\hline Outcome category & Outcome definition & Outcome subcategory \\
\hline 1. Population/Species Outcomes & $\begin{array}{l}\text { Outcomes focusing on change in populations of individuals or popu- } \\
\text { lations within species }\end{array}$ & $\begin{array}{l}\text { 1a. Abundance } \\
\text { 1b. Biomass } \\
\text { 1c. Age/Size Structure } \\
\text { 1d. Behavior } \\
\text { 1e. Recruitment } \\
\text { 1f. Reproduction } \\
\text { 1g. Species Range and Spatial Extent } \\
\text { 1h. Dispersal } \\
\text { 1i. Connectivity } \\
\text { 1j. Body Conditions } \\
\text { 1k. Adaptability }\end{array}$ \\
\hline 2. Ecological Community Outcomes & Outcomes focusing on change in community conditions & $\begin{array}{l}\text { 2a. Species Diversity } \\
\text { 2b. Trophic Structure } \\
\text { 2c. Functional Redundancy } \\
\text { 2d. Species Interactions } \\
\text { 2e. Habitat Quantity (Cover and Extent) } \\
\text { 2f. Habitat Quality } \\
\text { 2g. Habitat Connectivity }\end{array}$ \\
\hline 3. Ecosystem Function Outcomes & $\begin{array}{l}\text { Outcomes focusing on change in ecosystem processes and condi- } \\
\text { tions }\end{array}$ & $\begin{array}{l}\text { 3a. Productivity } \\
\text { 3b. Herbivory } \\
\text { 3c. Predation } \\
\text { 3d. Biogeochemistry } \\
\text { 3e. Coastal Processes }\end{array}$ \\
\hline 4. Ecosystem Services Outcomes & $\begin{array}{l}\text { Outcomes focusing on ecosystem services, as defined by Millenium } \\
\text { Ecosystem Assessment }\end{array}$ & $\begin{array}{l}\text { 4a. Provisioning Services } \\
\text { 4b. Regulating Services } \\
\text { 4c. Supporting Services } \\
\text { 4d. Cultural Services }\end{array}$ \\
\hline 5. Human Wellbeing Outcomes & $\begin{array}{l}\text { Outcomes related to changes in welfare of populations that rely } \\
\text { on areas where interventions are implemented; and/or program } \\
\text { beneficiaries }\end{array}$ & $\begin{array}{l}\text { 5a. Economic } \\
\text { 5b. Resource Based Livelihoods } \\
\text { 5c. Individual or Community Wellbeing } \\
\text { 5d. Food Security } \\
\text { 5e. Health } \\
\text { 5f. Education } \\
\text { 5g. Basic Infrastructure } \\
\text { 5h. Social Capital } \\
\text { 5i. Culture }\end{array}$ \\
\hline 6. Knowledge and Behavior Outcomes & $\begin{array}{l}\text { Outcomes related to awareness, knowledge, and/or behavior, or } \\
\text { response to new practices or technologies, for stakeholders }\end{array}$ & $\begin{array}{l}\text { 6a. Knowledge } \\
\text { 6b. Behavior/response to new practices } \\
\text { or technologies }\end{array}$ \\
\hline 7. Governance & $\begin{array}{l}\text { Structures and processes for decision-making, inc. formal and infor- } \\
\text { mal rules, participation in/control of decision making, accountabil- } \\
\text { ity, transparency, justice, empowerment }\end{array}$ & $\begin{array}{l}\text { 7a. Participation and Engagement } \\
\text { 7b. Political Capital } \\
\text { 7c. Institutions } \\
\text { 7d. Property Rights }\end{array}$ \\
\hline
\end{tabular}

studies by country or region along with summary plots and tables. This will allow us to identify priority areas for future research, evaluation, and theory development. Trends and patterns along with relevant insights for policy, practice and research will be summarized in a narrative report. The final dataset of included literature will be made available for future use and exploration through an open-access, interactive online portal. A data file of all literature screened, with reason for inclusion/exclusion and associated meta-data will also be made available upon completion.

\section{Supplementary information}

Supplementary information accompanies this paper at https://doi. org/10.1186/s13750-020-00193-w.

Additional file 1. Intervention framework

Additional file 2. Outcome framework.

Additional file 3. ROSES form for systematic map protocols.

Additional file 4. Evolution of search string.

Additional file 5. Article test library.

Additional file 6. Data coding questionnaire. 


\section{Acknowledgements}

The authors would like to thank the conservation experts who participated in informational interviews.

\section{Authors' contributions}

GA, LC, BS conceived the study and secured funding support. MR and WB developed the parameters of the study, search strategy, and inclusion/exclusion criteria, and developed the data coding protocol with SC and input from GA, LC, BS, DG, DAB, and LG. WB, MR, and LC wrote the manuscript with input from BS, GA, SC, and DG and LG. MR implemented the scoping of the search strategy and will coordinate review, data collection, analysis, and presentation of results. All authors read and approved the final manuscript.

\section{Funding}

This project is funded through the Duke University Bass Connections program and a gift from Jeff and Laurie Ubben to support collaboration between WWFU.S. and Duke University.

\section{Availability of data and materials}

Not applicable

\section{Ethics approval and consent to participate}

Not applicable.

\section{Consent for publication}

Not applicable.

\section{Competing interests}

The authors declare they have no competing interests.

\section{Author details}

${ }^{1}$ Duke University Marine Lab, Nicholas School of Environment, Duke University, 135 Duke Marine Lab Road, Beaufort, NC 28516, USA. ${ }^{2}$ Center for Biodiversity and Conservation, American Museum of Natural History, 200 Central Park West, New York, NY 10012, USA. ${ }^{3}$ Ocean Conservation, World Wildlife Fund-US, 1250 24th St. N.W, Washington, D.C 20037, USA. ${ }^{4}$ Global Science, World Wildlife Fund-US, 1250 24th Street N.W, Washington, D.C 20037, USA.

Received: 22 December 2019 Accepted: 29 April 2020

Published online: 13 May 2020

\section{References}

1. Hoegh-Guldberg O. Reviving the Ocean Economy: the case for action. 2015. https://espace.library.uq.edu.au/view/UQ:378844.

2. Neumann B, Vafeidis AT, Zimmermann J, Nicholls RJ. Future coastal population growth and exposure to sea-level rise and coastal floodinga global assessment. PLoS ONE. 2015;10(3):e0118571.

3. Barbier EB, Hacker SD, Kennedy C, Koch EW, Stier AC, Silliman BR. The value of estuarine and coastal ecosystem services. Ecol Monogr. 2011;81(2):169-93.

4. Mcleod E, Chmura GL, Bouillon S, Salm R, Björk M, Duarte CM, et al. A blueprint for blue carbon: toward an improved understanding of the role of vegetated coastal habitats in sequestering $\mathrm{CO}_{2}$. Front Ecol Environ. 2011;9(10):552-60.

5. Selig ER, Hole DG, Allison EH, Arkema KK, McKinnon MC, Chu J, et al. Mapping global human dependence on marine ecosystems. Conserv Lett. 2019:12:e12617. https://doi.org/10.1111/conl.12617.

6. FAO. The State of World Fisheries and Aquaculture 2018: Meeting the sustainable development goals. 2018. https://play.google.com/store/ books/details?id=Y3hjDwAAQBAJ.

7. Halpern BS, Walbridge S, Selkoe KA, Kappel CV, Micheli F, D’Agrosa C, et al. A global map of human impact on marine ecosystems. Science. 2008;319(5865):948-52

8. Lotze HK. Depletion, degradation, and recovery potential of estuaries and coastal seas. Science. 2006;312:1806-9. https://doi.org/10.1126/scien ce. 1128035
9. Waycott M, Duarte CM, Carruthers TJB, Orth RJ, Dennison WC, Olyarnik S, et al. Accelerating loss of seagrasses across the globe threatens coastal ecosystems. Proc Natl Acad Sci. 2009;106(30):12377-81.

10. Millennium Ecosystem Assessment. Ecosystem and human well-being: biodiversity synthesis. Washington, DC: World Resources Institute; 2005. p. $1-137$.

11. Duke N, Nagelkerken I, Agardy T, Wells S, Van Lavieren H. The importance of mangroves to people: a call to action. van Bochove J-W, Sullivan E, Nakamura T, editors. Cambridge, UK: United Nations Environment Programme World Conservation Monitoring Centre (UNEP-WCMC); 2014.

12. Burke L, Reytar K, Spalding M, Perry A. Reefs at risk revisited. 2011.

13. Campbell LM, Gray NJ, Fairbanks L, Silver JJ, Gruby RL, Dubik BA, et al. Global oceans governance: new and emerging issues. Annu Rev Environ Resour. 2016;41(1):517-43.

14. McLeod KL, Lubchenco J, Palumbi SR, Rosenberg AA. Scientific consensus statement on marine ecosystem-based management. Signed by 217 academic scientists and policy experts with relevant expertise. Communication Partnership for Science and the the Sea (COMPASS); 2005.

15. Associates, California Environmental. Our Shared Seas: A 2017 Overview of Ocean Threats and Conservation Funding. 2017. https://www.packa rd.org/insights/resource/global-ocean-report/.

16. Campbell LM, Gray NJ. Area expansion versus effective and equitable management in international marine protected areas goals and targets. Mar Policy. 2019;100:192-9.

17. Redford KH, Robinson JG, Adams WM. Parks as shibboleths. Conserv Biol. 2006;20(1):1-2

18. Adams WM, Aveling R, Brockington D, Dickson B, Elliott J, Hutton J, et al. Biodiversity conservation and the eradication of poverty. Science. 2004;306(5699):1146-9.

19. Pullin AS, Bangpan M, Dalrymple S, Dickson K, Haddaway NR, Healey JR, et al. Human well-being impacts of terrestrial protected areas. Environ Evid. 2013;2(1):19.

20. Campbell LM. Human need in rural developing areas: perceptions of wildlife conservation experts. Can Geogr. 2000;44(2):167-81.

21. Pascual U, Balvanera P, Díaz S, Pataki G, Roth E, Stenseke M, et al. Valuing nature's contributions to people: the IPBES approach. Curr Opin Environ Sustain. 2017;26:7-16

22. Campese J, Sunderland T, Greiber T, Oviedo G, editors. Rights-based Approaches: Exploring Issues and Opportunities for Conservation. Bogor, Indonesia: Center for International Forestry Research (CIFOR) and The International Union for Conservation of Nature (IUCN); 2009. 306 p.

23. Kareiva P, Marvier M. What is conservation science? Bioscience. 2012;62(11):962-9.

24. Bennett NJ, Teh L, Ota Y, Christie P, Ayers A, Day JC, et al. An appeal for a code of conduct for marine conservation. Mar Policy. 2017;81:411-8.

25. Gill DA, Cheng SH, Glew L, Aigner E, Bennett NJ, Mascia MB. Social synergies, tradeoffs, and equity in marine conservation impacts. Annu Rev Environ Resour. 2019;44:347-72. https://doi.org/10.1146/annurev-envir on-110718-032344.

26. Mascia MB, Claus CA, Naidoo R. Impacts of marine protected areas on fishing communities. Conserv Biol. 2010;24(5):1424-9.

27. McKinnon MC, Cheng SH, Garside R, Masuda YJ, Miller DC. Sustainability: map the evidence. Nature. 2015:528:185-7. https://doi. org/10.1038/528185a.

28. Woodcock $\mathrm{P}, \mathrm{O}^{\prime}$ Leary BC, Kaiser MJ, Pullin AS. Your evidence or mine? Systematic evaluation of reviews of marine protected area effectiveness. Fish Fish. 2017;18(4):668-81.

29. Sciberras M, Jenkins SR, Kaiser MJ, Hawkins SJ, Pullin AS. Evaluating the biological effectiveness of fully and partially protected marine areas. Environ Evid. 2013:2(1):4.

30. Mizrahi M, Diedrich A, Weeks R, Pressey RL. A systematic review of the socioeconomic factors that influence how marine protected areas impact on ecosystems and livelihoods. Soc Nat Resour. 2018;32:1-17.

31. Papathanasopoulou E, Queirós AM, Beaumont N, Hooper T, Nunes J. What evidence exists on the local impacts of energy systems on marine ecosystem services: a systematic map. Environ Evid. 2016:5(1):25.

32. Rodrigues JG, Conides AJ, Rivero Rodriguez S, Raicevich S, Pita P, Kleisner $\mathrm{KM}$, et al. Marine and coastal cultural ecosystem services: knowledge 
gaps and research priorities. One Ecosyst 2. 2017; https://www.repo.unihannover.de/handle/123456789/4311.

33. Arton A, Leiman A, Petrokofsky G, Toonen H, Neat F, Longo CS. What do we know about the impacts of the Marine Stewardship Council seafood ecolabelling program? A systematic map protocol. Environ Evid. 2018;7(1):29.

34. Liquete C, Piroddi C, Drakou EG, Gurney L, Katsanevakis S, Charef $A$, et al. Current status and future prospects for the assessment of marine and coastal ecosystem services: a systematic review. PLoS ONE. 2013;8(7):e67737.

35. Conservation Measures Partnership. Classification of Conservation Actions and Threats. Version 2.0. 2016.

36. McKinnon MC, Cheng SH, Dupre S, Edmond J, Garside R, Glew L, et al. What are the effects of nature conservation on human well-being? A systematic map of empirical evidence from developing countries. Environ Evid. 2016;5(1):8.

37. Puri J, Nath M, Bhatia R, Glew L. Examining the evidence base for forest conservation interventions. Int Initiat Impact Eval Evidence Gap Map Rep. 2016:4:1-70.

38. Snilstveit B, International Initiative for Impact Evaluation (3ie), Stevenson J, Villar PF, Eyers J, Harvey C, et al. Land-use change and forestry programmes: evidence on the effects on greenhouse gas emissions and food security. 2016. http://dx.doi.org/10.23846/egm003.

39. Mascia MB, Fox HE, Glew L, Ahmadia GN, Agrawal A, Barnes M, et al. A novel framework for analyzing conservation impacts: evaluation, theory, and marine protected areas. Ann N Y Acad Sci. 2017;1399(1):93-115.

40. Larson AM, Soto F. Decentralization of Natural Resource Governance Regimes. Annu Rev Environ Resour. 2008;33(1):213-39.

41. Haddaway NR, Macura B, Whaley P, Pullin AS. ROSES RepOrting standards for Systematic Evidence Syntheses: pro forma, flow-diagram and descriptive summary of the plan and conduct of environmental systematic reviews and systematic maps. Environ Evid. 2018;7(1):7.

42. Cheng SH, Augustin C, Bethel A, Gill D, Anzaroot S, Brun J, et al. Using machine learning to advance synthesis and use of conservation and environmental evidence. Conserv Biol. 2018:32(4):762-4.

\section{Publisher's Note}

Springer Nature remains neutral with regard to jurisdictional claims in published maps and institutional affiliations.
Ready to submit your research? Choose BMC and benefit from:

- fast, convenient online submission

- thorough peer review by experienced researchers in your field

- rapid publication on acceptance

- support for research data, including large and complex data types

- gold Open Access which fosters wider collaboration and increased citations

- maximum visibility for your research: over $100 \mathrm{M}$ website views per year

At $\mathrm{BMC}$, research is always in progress.

Learn more biomedcentral.com/submissions 